\title{
Is the Game Over or Starting Again? The Role of the Transplant Team in Genetic Counseling for Adult Sickle Cell Disease Recipients
}

\author{
Oyun Bitti mi Yoksa Yeniden mi Başlıyor? Erişkin Orak Hücre Hastalığı Olan Alıcılarda \\ Genetik Danışmanlıkta Nakil Ekibinin Rolü
}

Pelin Aytan ${ }^{1}$, Çiğdem Gereklioğlu², Mahmut Yeral ${ }^{1}$, Aslı Korur ${ }^{1}$, Süheyl Asma ${ }^{1}$, Illknur Kozanoğlu ${ }^{1}$, Hakan Özdoğu ${ }^{1}$, Can Boğa ${ }^{1}$

${ }^{1}$ Başkent University Training and Research Hospital, Bone Marrow and Stem Cell Transplantation Center, Clinic of Hematology, Adana, Turkey

${ }^{2}$ Başkent University Faculty of Medicine, Department of Family Medicine, Adana, Turkey

To the Editor,

Hematopoietic stem cell transplantation (HSCT) with nonmyeloablative regimens has become more feasible and it is currently performed more frequently in adult patients with sickle cell disease (SCD) [1]. Hsieh [1] reported successful outcomes for adults with a regimen of alemtuzumab and low-dose total body irradiation (TBI) in transplants from human leukocyte antigen (HLA)-matched sibling donors. We have obtained sustained full chimerism in 13 adults with protocols including antithymocyte globulin (ATG) and busulfan without any significant complications (unpublished data). For unrelated donors, the ongoing STRIDE study uses conditioning regimens containing ATG, fludarabine, and busulfan. Bolaños-Meade et al. [2] achieved a cure with HLA-haploidentical transplants performed with ATG, fludarabine, and low-dose TBI. Given that these protocols may allow assisted or spontaneous pregnancies, fertility issues need to be examined [3] because the patient may think that he/she is completely cured after allogeneic transplantation and that he/she no longer carries the hemoglobin $S(H b S)$ gene. This erroneous belief may lead to the delivery of a homozygous $\mathrm{Hb} S \mathrm{~S}$ infant if the partner has a high risk of being a $H b S$ gene carrier when marriages of close relatives occur, as in some populations like Eti-Turks.

SCD is the most common hereditary disease worldwide. The impaired microcirculation caused by rigid erythrocytes leads to considerable mortality and severe morbidity if not managed appropriately [4]. The only proven curative therapy is HSCT. However, this treatment carries high risk for infertility as a major complication for young patients [5]. Factors predisposing to infertility in these patients include delayed puberty, priapism, and gonadal dysfunction with increased abnormal spermatozoa, seminal vesicle and prostate gland abnormalities, decreased ejaculate volume, lower testosterone levels, and low sperm counts in males $[6,7,8]$. Conditioning regimens including alemtuzumab and low-dose TBI are reported not to irreparably impair spermatogenesis, although there are insufficient data about non-myeloablative conditioning including ATG and busulfan [9].

When young SCD patients want to marry after full recovery with transplantation, some of them tend to hide their disease intentionally or due to a lack of awareness. A complete blood count and hemoglobin electrophoresis test as part of the screening done before marriage may give normal results. Consequently, affected germ cells may be overlooked. This may result in giving birth to affected children. The transplant team is responsible for providing sufficient information about these issues.

Keywords: Adult, Sickle cell anemia, Genetic counseling, Transplantation

Anahtar Sözcükler: Erişkin, Orak hücreli anemi, Genetik danışmanlık, Transplantasyon

Conflict of Interest: The authors of this paper have no conflicts of interest, including specific financial interests, relationships, and/ or affiliations relevant to the subject matter or materials included.

\section{References}

1. Hsieh MM. A standard nonmyeloablative transplantation regimen for adults with sickle cell disease: are we there yet? Biol Blood Marrow Transplant 2016;22:397-398.

2. Bolaños-Meade J, Fuchs EJ, Luznik L, Lanzkron SM, Gamper CJ, Jones RJ, Brodsky RA. HLA-haploidentical bone marrow transplantation with posttransplant cyclophosphamide expands the donor pool for patients with sickle cell disease. Blood 2012;120:4285-4291.

3. Tichelli A, Rovó A. Fertility issues following hematopoietic stem cell transplantation. Expert Rev Hematol 2013;6:375-388.

4. Karacaoglu PK, Asma S, Korur A, Solmaz S, Buyukkurt NT, Gereklioglu C, Kasar M, Ozbalcı D, Unal S, Kaya H, Gurkan E, Yeral M, Sariturk Ç, Boga C, Ozdogu $\mathrm{H}$. East Mediterranean region sickle cell disease mortality trial: retrospective multicenter cohort analysis of 735 patients. Ann Hematol 2016;95:993-1000.

5. Özdoğu H, Boğa C. Hematopoietic stem cell transplantation in adult sickle cell disease: problems and solutions. Turk J Hematol 2015;32:195-205. 
6. Oncofertility Consortium. Sickle Cell Anemia. Chicago, Northwestern University, 2014. Available online at http://oncofertility.northwestern.edu/ resources/sickle-cell-anemia.

7. Agbaraji VO, Scott RB, Leto S, Kingslow LW. Fertility studies in sickle cell disease: semen analysis in adult male patients. Int J Fertil 1988;33:347-352.
8. Abudu EK, Akanmu SA, Soriyan 00, Akinbami AA, Adediran A, Adeyemo TA, Okany CO. Serum testosterone levels of HbSS (sickle cell disease) male subjects in Lagos, Nigeria. BMC Res Notes 2011;4:298.

9. Gharwan H, Neary NM, Link M, Hsieh MM, Fitzhugh CD, Sherins RJ, Tisdale JF. Successful fertility restoration after allogeneic hematopoietic stem cell transplantation. Endocr Pract 2014;20:157-161.

\title{
Assessment of Quality of Life of Chronic Myeloid Leukemia Patients by Using the EORTC QLQ-C30
}

\section{Kronik Miyeloid Lösemili Hastaların Yaşam Kalitesinin EORTC QLQ-C30 Anketi Kullanılarak Değerlendirilmesi}

\author{
Mehmet Can Uğur ${ }^{1}$, Yaşar Bekir Kutbay², Özge Özer Kaya² ${ }^{2}$ Cengiz Ceylan³ \\ ${ }^{1}$ Tepecik Training and Research Hospital, Clinic of Internal Medicine, Izmir, Turkey \\ ${ }^{2}$ Tepecik Training and Research Hospital, Genetic Diagnostic Center, Izmir, Turkey \\ ${ }^{3}$ Tepecik Training and Research Hospital, Clinic of Hematology, Izmir, Turkey
}

To the Editor,

Depression is determined in 15\%-25\% of patients with cancer and it is accepted as a comorbid problem with poor prognosis. The quality of life of these patients is determined to be poor $[1,2]$. We aimed to study the quality of life of patients using new forms of imatinib, dasatinib, or nilotinib.

We analyzed 56 chronic myeloid leukemia patients followed in the İzmir Tepecik Training and Research Hospital Department of Hematology. Patients were followed from 2005 to 2015. We included patients who were $>18$ years of age, BCR-ABL-positive based on polymerase chain reaction results, using first- or second-generation tyrosine kinase inhibitors (TKIs) in the last 6 months, and in the chronic phase of the disease.

The Turkish version of the European Organisation for Research and Treatment of Cancer Quality of Life Questionnaire-C30 (EORTC OLQ-C30) [3], the Turkish version of the Hospital Anxiety and Depression Scale [4], and the General Health Questionnaire [5] were administered to patients one-on-one. The study received approval from the ethics committee.
The demographic data and laboratory values are provided in Table 1.

In our study, we found no statistical significance between firstand second-generation TKIs. We also compared dasatinib and nilotinib as subgroups of the second generation and we found statistical significance for dasatinib against nilotinib for general life quality, emotional and cognitive functions, and fatigue parameters.

Keywords: Cytogenetic, Chronic myeloid leukemia, Molecular hematology, Life-quality, Dasatinib, Nilotinib

Anahtar Sözcükler: Sitogenetik, Kronik miyeloid lösemi, Moleküler hematoloji, Yaşam kalitesi, Dasatinib, Nilotinib

Conflict of Interest: The authors of this paper have no conflicts of interest, including specific financial interests, relationships, and/or affiliations relevant to the subject matter or materials included. 